\title{
KEDUDUKAN PEMBAGIAN HARTA WARISAN BAGI AHLI WARIS KHUNTSA DALAM PERSPEKTIF KEMAJUAN TEKNOLOGI
}

\author{
Riana Kesuma Ayu \\ Sekolah Tinggi Ilmu Hukum Sultan Adam Banjarmasin \\ Jl. Sultan Adam No.130, Kalimantan Selatan, Indonesia 70122 \\ Email:ayu@stihsa.ac.id
}

Submitted:25/07/2020 Reviewed: 29/09/2020 Accepted:30/09/2020

\begin{abstract}
The parts of the heirs have been determined in the Qur'an and the Sunnah of the Apostles, namely as stipulated in the Qur'an surah An-Nisa Verse 7 which in this verse stipulates that men and women alike has the right to inheritance from parents (mother and father and his immediate family). In the Compilation of Islamic Law which is used as the legal basis of Islamic Inheritance in Indonesia, none of them contain the discussion and distribution of inheritance for experts in the Khuntsa Wazris. The purpose of this research are: (1) to analyze and find the legal concept of inheritance distribution for khuntsa heirs according to Faraid law, and (2) to analyze and find the concept of resolving disputes in the distribution of inheritance for khuntsa heirs. The results of this study are: (1) The Concept of Legal Division of Khuntsa Inheritors in the Faraidh Law, which is most close to a sense of justice is to take an average of two estimates, so that both male and female estimates are the result of adding and dividing by two. And (2) the concept of resolving the dispute of the Khuntsa Heirs in the Faraidh Law can be done by using the concept of Ishlah (reconciling) in a family manner that is based on the agreement of the heirs
\end{abstract}

Keywords: Distribution of inheritance; Khuntsa Heirs

Abstrak: Bagian-bagian para ahli waris telah ditetapkan dalam Al-Qur'an dan Sunah Rasul, yaitu sebagaimana telah ditetapkan dalam Al-Qur'an surah An-Nisa Ayat 7 yang pada ayat ini ditetapkan bahwa laki-laki dan perempuan sama-sama mempunyai hak atas warisan orang tua (Ibu dan Bapak serta keluarga terdekatnya). Dalam Kompilasi Hukum Islam yang dipakai sebagai dasar hukum Kewarisan Islam di Indonesia tidak ada satupun yang memuat bahasan dan pembagian harta warisan bagi ahli waris khuntsa. Adapun tujuan dari penelitian ini adalah: (1) untuk menganalisis dan menemukan konsep hukum pembagian harta warisan bagi ahli waris khuntsa menurut hukum Faraid, dan (2) untuk menganalisis dan 
menemukan konsep penyelesain sengketa dalam pembagian harta warisan bagi ahli waris khuntsa. Hasil dari penelitian ini adalah: (1) Konsep Pembagian Hukum Ahli Waris khuntsa dalam Hukum Faraidh, yang paling mendekati rasa keadilan adalah dengan mengambil bagian rata-rata dari dua perkiraan, sehingga baik diperkirakan laki-laki ataupun perempuan hasilnya ditambah dan dibagi dua. Dan (2) Konsep Penyelesain Sengketa Ahli Waris Khuntsa dalam Hukum Faraidh bisa dilakukan dengan memakai konsep Ishlah (mendamaikan) secara kekeluargaan yaitu berdasarkan kesepakatan para ahli waris

Kata Kunci: pembagian harta warisan; ahli waris khuntsa

\section{PENDAHULUAN}

Hukum Waris menduduki tempat amat penting dalam Hukum Islam. Ayat Al-Qur'an mengatur Hukum Waris dengan jelas dan terperinci. Hal ini dapat di mengerti sebab masalah kewarisan pasti dialami oleh setiap orang. Kecuali itu, Hukum Waris langsung menyangkut harta benda yang apabila tidak diberikan ketentuan pasti, amat mudah menimbulkan sengketa ahli waris. ${ }^{1}$

Sedemikian penting kedudukan Hukum Waris dalam Hukum Islam sehingga Hadist Nabi riwayat Ibnu Majah dan Addaraquthni mengajarkan: "Pelajarilah Faraidh dan ajarkanlah kepada orang banyak karena Faraidh adalah setengah ilmu dan mudah dilupakan serta merupakan ilmu yang pertama kali hilang dari umatku". ${ }^{2}$

Bagian-bagian para ahli waris telah ditetapkan dalam Al-Qur'an dan Sunah Rasul, yaitu sebagaimana telah ditetapkan dalam AlQur'an surah An-Nisa Ayat 7 yang pada ayat ini ditetapkan bahwa laki-laki dan perempuan sama-sama mempunyai hak atas warisan orang tua (Ibu dan Bapak serta keluarga terdekatnya). Mereka yang mendapatkan warisan tersebut ada yang mendapat bagian

\footnotetext{
1 Ahmad Azhar Basyir, Hukum Waris Islam, (Yogyakarta: Penerbit UII Press, 2001), 3.

2 Ibid., 4.
}

banyak dan ada pula yang sedikit berdasarkan bagian yang ditetapkan. Ayat ini mengatur penegasan bahwa laki-laki dan perempuan dapat mewarisi dan ditegaskan dengan sebutan yang sama berupa bagian laki-laki dan bagian perempuan, yaitu berupa bagian warisan dari apa yang ditinggalkan ibu bapaknya dan kerabatnya. ${ }^{3}$

Pada hakikatnya setiap manusia memiliki hak untuk menerima hak kewarisan dari orang orang yang telah meninggal (pewaris) selama mempunyai hubungan nasab dan hubungan pernikahan dengannya. Namun ada beberapa faktor juga yang menghalangi seseorang dalam menerima hak kewarisannya yaitu: karena perbudakan, pembunuhan, dan perbedaan agama antara pewaris dengan yang menerima warisan. ${ }^{4}$

Wujud warisan atau harta peninggalan menurut hukum Islam berbeda dengan wujud warisan hukum Barat juga hukum waris Adat. Warisan menurut hukum Islam adalah "sejumlah harta benda serta segala hak dari yang meninggal dunia dalam keadaan bersih" artinya harta peninggalan yang diwarisi

\footnotetext{
3 Sayuti Thalib, Hukum Kewarisan Islam di Indonesia, (Jakarta: Penerbit Sinar Grafika, 1995), 4.

4 Rizkal, "Pemberian Hak Waris dalam Hukum Islam Kepada Non-Muslim Berdasarkan Wasiat Wajibah," Jurnal Yudisial 9, no. 2 (2016): 174, https://jurnal. komisiyudisial.go.id/index.php/jy/article/view/23
} 
oleh para ahli waris adalah sejumlah harta benda serta segala hak, "setelah dikurangi dengan pembayaran hutang-hutang pewaris dan pembayaran pembayaran lain yang diakibatkan oleh wafatnya si pewaris". ${ }^{5}$

Namun bagi ahli waris yang nyata keberadaannya yaitu sudah diketahui jenis kelaminnya, laki-laki atau perempuan (tidak banci/khuntsa) dan tidak berada dalam kandungan ibunya, serta tidak hilang (mafqud) untuk pembagian harta warisan tidaklah ada masalah. Karena sudah ada ketentuan hukumnya secara tegas, jelas, dan terperinci di dalam Al-Qur'an dan bilamana tidak terdapat padanya lebih lanjut diatur oleh Hadis Nabi yang shahih, yang menjadi permasalahan adalah jika ada ahli waris yang pembagian warisnya masih tidak jelas dan tidak dijelaskan dalam ketentuan syariat tentang pembagian mereka hal inilah yang termasuk dalam kelompok ahli waris Miratsut Taqdiri yaitu bagian warisnya diperoleh dengan jalan atau dengan cara kira-kira, dengan melakukan perhitungan perkiraan dari dua kemungkinan. Seperti mereka yang terlahir dalam keadaan yang tidak normal yaitu memiliki dua jenis kelamin/berkelamin ganda (khuntsa/banci) tidak ditetapkan dan dijelaskan dalam ayat-ayat mawaris, sedangkan dalam ketentuan hukum Faraidh pembagian anak perempuan dan anak lakilaki sudah jelas, anak perempuan satu bagian serta anak laki-laki dua bagian, sama halnya juga dengan ada kemungkinan terjadi waris anak yang masih dalam kandungan ibunya, bahwa masa kelahiran masih lama setelah

${ }^{5}$ Sofyan Mei Utama, "Kedudukan Ahli Waris Pengganti dan Prinsip Keadilan dalam Hukum Waris Islam," Jurnal Wawasan Yuridika 34, no. 1 (2016): 73, http://ejournal.sthb.ac.id/index.php/jwy/article/ view/109 matinya si pewaris. Dalam hal demikian harta warisan bisa dibagi kepada waris yang ada dan untuk anak yang masih dalam kandungan, bagaimana pembagian warisnya sedangkan masih belum diketahui anak dalam kandungan tersebut berjenis kelamin laki-laki atau perempuan, sekalipun telah diketahui jenis kelaminnya melalui hasil USG kedokteran tidak bisa dipastikan apakah anak terlahir dalam keadaan hidup atau mati. Ahli waris yang termasuk kelompok Miratsut Taqdiri adalah orang yang Mafqud (hilang) ialah orang yang sudah lama pergi meninggalkan tempat tinggalnya dan tidak diketahui kabar beritanya, tempat tinggalnya (domisilinya) dan tidak diketahui pula tentang hidup dan matinya.

Berdasarkan uraian tersebut diatas pembahasan pembagian waris Khuntsa (banci), anak dalam kandungan, dan orang yang Mafqud (hilang) merupakan ahli waris yang termasuk dalam kelompok Miratsut Taqdiri, yang dalam bahasan hukum Faraidh tidak ada ketentuan yang pasti tentang bagian mereka, waris mewaris atau pusaka mempusakai dengan cara/jalan perkiraan. Dalam Kompilasi Hukum Islam yang dipakai sebagai dasar hukum Kewarisan Islam di Indonesia tidak ada satupun yang memuat bahasan dan pembagian mereka yang termasuk dalam kelompok Miratsut Taqdiri ini. Dengan demikian penulis sangat tertarik membahas dan menulis kajian hukum mengenai hal ini, yaitu bagaimana konsep pembagian dan penyelesaian sengketa ahli waris yang termasuk dalam kelompok ahli waris Miratsut Taqdiri ini dalam ketentuan hukum Faraidh, dengan menemukan konsep tata cara pembagian dan penyelesaiannya diharapkan dapat membantu para perumus dan penyusun peraturan hukum positif di 
Indonesia untuk memuat aturan ketentuan pembagian waris bagi mereka yang termasuk kelompok Miratsut Taqdiri, salah satunya masuk dalam konsep rumusan Kompilasi Hukum Islam yang akan direvisi, dan mudahmudahannya kedepan Kompilasi Hukum Islam yang bentuknya hanyalah Instruksi Presiden bisa dinaikkan menjadi UndangUndang sebagai dasar acuan bagi hakim Pengadilan Agama untuk memutus sengketa waris Islam.

Dalam pembahasan mengenai ahli waris khuntsa/banci ini, penulis memberikan batasan dan rumusan masalah adalah sebagai berikut:

1. Bagaimana Konsep Hukum Pembagian harta Warisan bagi ahli waris khuntsa menurut Hukum Faraidh?

2. Bagaimana Konsep Hukum Penyelesaian Sengketa Ahli Waris khuntsa dalam Hukum Faraidh?

Berdasarkan rumusan masalah tersebut diatas, maka tujuan dari penelitian ini adalah sebagai berikut:

1. Untuk menganalisis dan menemukan konsep hukum pembagian harta warisan bagi ahli waris khuntsa menurut hukum Faraidh.

2. Untuk menganalisis dan menemukan konsep penyelesain sengketa dalam pembagian harta warisan bagi ahli waris khuntsa

\section{METODE}

\section{Jenis Penelitian}

Penelitian ini menggunakan jenis penelitian normatif, yaitu penelitian yang bertolak pada suatu proses guna mendapatkan kaidah hukum, prinsip-prinsip hukum dan doktrin-doktrin hukum untuk memberikan jawaban atau isu hukum yang dihadapi sehingga diperoleh argumentasi, teori atau konsep baru sebagai preskripsi dalam menyelesaikan masalah.

\section{Pendekatan Penelitian}

Penelitian ini menggunakan pendekatan perundang-undangan (statute approach) dan pendekatan konsep (conceptual approach). Pendekatan perundang-undangan merupakan pendekatan terhadap norma-norma yang termuat dalam peraturan perundangundangan yang mengatur tentang pembagian waris, sedangkan pendekatan konseptual merupakan pendekatan yang mengacu pada pendapat dan doktrin dalam ilmu hukum guna memperoleh ide-ide yang melahirkan konsepkonsep hukum dan prinsip-prinsip hukum yang relevan dengan pokok bahasan.

\section{Sifat Penelitian}

Penelitian ini bersifat deskriptif analitis, yaitu suatu penelitian yang bertujuan menggambarkan atau menjelaskan gejala hukum, dalam hal ini menemukan konsep yang tepat dalam penyelesaian pembagian ahli waris khuntsa.

\section{Sumber Bahan Hukum}

Ada dua bagian dari bahan hukum yaitu bahan hukum primer dan bahan hukum sekunder, yaitu :

1. Bahan hukum primer adalah bahan hukum yang bersifat mengikat: Al-Qur'an dan Hadis; Undang-Undang Dasar Tahun 1945; Undang-Undang Nomor 3 Tahun 2006 tentang Pengadilan Agama; Instruksi Presiden Nomor 1 Tahun 1991 tentang Kompilasi Hukum Islam; Keputusan Menteri Agama Nomor 154 Tahun 1991

2. Bahan hukum sekunder adalah bahan hukum berupa buku-buku teks, jurnal hukum dan pendapat ahli hukum yang relevan dengan pokok bahasan.

3. Bahan hukum tersier adalah bahan hukum 
yang memberikan penjelasan terhadap bahan hukum primer dan bahan hukum sekunder seperti kamus hukum dan ensiklopedia.

Teknik Pengumpulan dan Pengolahan

\section{Bahan Hukum}

Bahan-bahan hukum yang dipergunakan dalam penelitian ini dikumpulkan melalui studi pustaka yaitu penelitian dengan cara memeriksa, penandaan, rekonstruksi dan sistematika.

\section{Analisa Bahan Hukum}

Bahan-bahan hukum yang telah diolah kemudian dianalisis secara kualitatif, yaitu penganalisaan tanpa menggunakan angkaangka melainkan membuat kesimpulan atas hasil penafsiran terhadap aturan hukum yang relevan dengan pokok bahasan.

\section{ANALISIS DAN PEMBAHASAN}

Konsep Hukum Pembagian Ahli Waris khuntsa dalam Hukum Faraidh

\section{Ahli Waris Khuntsa}

Pengertian al-khuntsa (banci) dalam bahasa Arab diambil dari kata khanatsa berarti lunak atau melunak. Misalnya, khanatsa wa takhannatsa, yang berarti apabila ucapan atau cara jalan seorang laki-laki menyerupai wanita: lembut dan melenggak-lenggok. Karenanya dalam hadits sahih dikisahkan bahwa Rasulullah saw. bersabda: "Allah SWT melaknat lakilaki yang menyerupai wanita dan wanita yang menyerupai laki-laki."

Makna khantsa menurut para fuqaha adalah orang yang mempunyai alat kelamin laki-laki dan kelamin wanita (hermaphrodit), atau bahkan tidak mempunyai alat kelamin sama sekali. Keadaan yang kedua ini menurut para fuqaha dinamakan khuntsa musykil, artinya tidak ada kejelasan. Sebab, setiap insan seharusnya mempunyai alat kelamin yang jelas, bila tidak berkelamin laki-laki berarti berkelamin perempuan.

Kejelasanjenis kelamin seseorang akan mempertegas status hukumnya sehingga ia berhak menerima harta waris sesuai bagiannya. Oleh karena itu, adanya dua jenis kelamin pada seseorang atau bahkan sama sekali tidak ada disebut sebagai musykil. Keadaan ini membingungkan karena tidak ada kejelasan, kendatipun dalam keadaan tertentu kemusykilan tersebut dapat diatasi, misalnya dengan mencari tahu dari mana ia membuang "air kecil”. Bila urinenya keluar dari penis, maka ia divonis sebagai laki-laki dan mendapatkan hak waris sebagaimana kaum laki-laki. Sedangkan jika ia mengeluarkan urine dari vagina, ia divonis sebagai wanita dan memperoleh hak waris sebagai kaum wanita. Namun, bila ia mengeluarkan urine dari kedua alat kelaminnya (penis dan vagina) secara berbarengan, maka inilah yang dinyatakan sebagai khuntsa munsykil. Dan ia akan tetap musykil hingga datang masa akil baligh.

Disini akan dikemukakan contoh perhitungan untuk ahli waris Khuntsa, yaitu:

Seseorang meninggal dunia dengan meninggalkan ahli waris anak laki-laki dan anak Khuntsa Musykil, dan harta warisannya tanah seluas 72 hektar (Ha).

Tabel 1 Jika si Khuntsa Musykil diperkirakan laki-laki:

\begin{tabular}{lllll}
\hline $\begin{array}{l}\text { Ahli } \\
\text { Waris }\end{array}$ & Fard & AM=2 & $\begin{array}{l}\text { Harta } \\
\text { Warisan }\end{array}$ & Hasil \\
\hline Anak & Ashabah & $1 / 2$ & $1 \times \frac{72 \mathrm{Ha}}{2}$ & $36 \mathrm{Ha}$ \\
Lk & Binafsihi & & \multicolumn{2}{c}{2} \\
\hline
\end{tabular}




\begin{tabular}{llccc}
\hline Anak & Ashabah & $1 / 2$ & $1 \times \frac{72 \mathrm{Ha}}{2}$ & $36 \mathrm{Ha}$ \\
Lk & Binafsihi & & & \\
\hline
\end{tabular}

Tabel 2. Jika si Khuntsa Musykil diperkirakan

\begin{tabular}{llccl}
\multicolumn{5}{c}{ perempuan: } \\
\hline $\begin{array}{l}\text { Ahli } \\
\text { Waris }\end{array}$ & Fard & AM=2 & $\begin{array}{l}\mathrm{H} \text { a r t a } \\
\text { Warisan }\end{array}$ & Hasil \\
\hline Anak & $\begin{array}{l}\text { Ashabah } \\
\text { Lk }\end{array}$ & $2 / 3$ & $2 \times \frac{72 \mathrm{Ha}}{3}$ & $48 \mathrm{Ha}$ \\
\hline Bnak Prairi & $\begin{array}{l}\text { Ashabah } \\
\text { Bilghairi }\end{array}$ & $1 / 3$ & $1 \times \underline{72 \mathrm{Ha}}$ & $24 \mathrm{Ha}$ \\
& & & \\
\hline
\end{tabular}

Ada tiga pendapat yang masyhur di kalangan ulama mengenai pemberian hak waris kepada banci musykil ini:

1. Mazhab Hanafi berpendapat bahwa hak waris banci adalah yang paling (lebih) sedikit bagiannya di antara keadaannya sebagai laki-laki atau wanita. Dan ini merupakan salah satu pendapat Imam Syafii serta pendapat mayoritas sahabat. Dengan demikian berdasarkan contoh tersebut diatas, maka Khuntsa menurut mazhab Hanafi menerima bagian yang terkecil dari dua perkiraan yaitu $24 \mathrm{Ha}$.

2. Mazhab Maliki berpendapat, pemberian hak waris kepada para banci hendaklah tengah-tengah di antara kedua bagiannya. Maksudnya, mulamula permasalahannya dibuat dalam dua keadaan, kemudian disatukan dan dibagi menjadi dua, maka hasilnya menjadi hak/bagian banci. Berdasarkan contoh diatas maka bagian Khuntsa menurut mazhab Maliki adalah:

a. anak laki-laki menerima bagian $\frac{36 \mathrm{Ha}+48 \mathrm{Ha}}{2}=42 \mathrm{Ha}$

b. khuntsa menerima bagian

c. $\underline{36 \mathrm{Ha}+24 \mathrm{Ha}}=30 \mathrm{Ha}$ 2

3. Mazhab Syafii berpendapat, bagian setiap ahli waris dan banci diberikan dalam jumlah yang paling sedikit. Karena pembagian seperti ini lebih meyakinkan bagi tiap-tiap ahli waris. Sedangkan sisanya (dari harta waris yang ada) untuk sementara tidak dibagikan kepada masing-masing ahli waris hingga telah nyata keadaan yang semestinya. Inilah pendapat yang dianggap paling rajih (kuat) di kalangan mazhab Syafii. Berdasarkan contoh diatas maka bagian Khuntsa menurut mazhab Syafii adalah:

a. anak laki-laki dari dua perkiraan 36 $\mathrm{Ha}$

b. khuntsa bagian yang terkecil dari dua perkiraan $24 \mathrm{Ha}$ jumlah $36 \mathrm{Ha}$ $+24 \mathrm{Ha}=60 \mathrm{Ha}$, jadi masih ada sisa lebih sebesar $72 \mathrm{Ha}-60 \mathrm{Ha}=$ 12 Ha. Sisa ditangguhkan dahulu, sampai persoalan Khuntsa menjadi jelas atau ada perundingan bersama untuk saling hibah menghibahkan.

Para faradhiyun mengidentifikasikan khuntsa kepada laki-laki atau perempuan menempuh dua jalan, yakni sebagai berikut:

1. Dengan cara meneliti alat kelamin

Seorang khuntsa membuang air kecil melalui dzakar atau melalui dzakar dan farj, tetapi air yang lewat dzakar lebih dahulu keluarnya daripada yang melalui farj, ia dianggap sebagai laki-laki dan karenanya ia dalam mewarisi sebagaimana seorang lakilaki. Jika ia membuang air kecil dengan melalui farj atau melalui farj dan dzakar, tetapi yang melalui farj lebih dulu keluarnya, ia dianggap sebagai perempuan dan karenanya dapat mewarisi sebagaimana orang 
perempuan. Sandaran yang digunakan untuk menentukan laki-laki atau perempuan dari seorang khuntsa adalah sabda Rasulullah saw yang disampaikan kepada para sahabat atas pertanyaan seorang sahabat, dikala beliau sedang menimang anak khuntsa Anshar. Beliau bersabda, yang artinya: "Berikanlah warisan anak khuntsa ini (seperti bagian lakilaki atau perempuan) mengingat dari alat kelamin yang mula pertama dipergunakannya untuk berkencing" (HR Ibnu Abbas) Menurut Ibnu Mundzir bahwa penetapan untuk memberi pusaka kepada anak khuntsa menurut cara semacam ini telah disepakati oleh seluruh fuqaha. ${ }^{6}$

2. Meneliti tanda-tanda kedewasaannya Jika penelitian alat kelamin yang digunakan tidak berhasil, ditempuhlah jalan yang kedua ini. Ciri-ciri yang spesifik bagi laki-laki dewasa adalah tumbuh jenggot dan kumisnya, suara berubah menjadi besar, keluar sperma dan adanya kecenderungan menyukai wanita. Adapun ciri-ciri spesifik bagi wanita dewasa adalah buah dada membesar, menstruasi, dan adanya kecenderungan menyukai lakilaki. ${ }^{7}$ Namun, pada saat ini dengan adanya alat yang canggih tidaklah sulit untuk mengetahui suatu jenis kelamin. Adapun para ulama klasik menetapkan kepastian ini dengan tanda-tanda yang ada. ${ }^{8}$ Selama masih

${ }^{6}$ Fathurrahman, Ilmu Waris, (Bandung : Al-Maarif, 1975), 483.

7 Ibid., 484.

8 Amir Syarifuddin, Hukum Kewarisan Islam, (Jakarta: Kencana, 2004), 239. diketahui jenis kelamin khuntsa itu dengan menggunakan cara dan tanda apapun, ia tetap disebut khuntsa yang bukan musykil dan hak warisnya dapat dipastikan. Jika dengan segala cara dan tanda tersebut di atas tidak dapat memastikan jenis kelaminnya, ia dinyatakan sebagai khuntsa musykil dan kewarisannya ditangguhkan sampai jelas statusnya. Para ulama faradhiyun sepakat dalam menghitung kadar bagian khuntsa musykil dengan memperkirakan dan menghitungnya sebagai laki-laki kemudian sebagai perempuan, namun mereka berselisih pendapat dalam menerimakan bagian khuntsa musykil tersebut. Jalan tersebut adalah yang ditempuh oleh para ulama faradhiyun dalam menentukan jumlah bagian khuntsa musykil.

\section{Ahli Waris Anak Dalam Kandungan}

Pada dasarnya, anak baru berhak waris apabila lahir dalam keadaan hidup, meskipun demikian apabila waktu kelahiran masih lama setelah kematian yang mewariskan, harta warisan sudah dapat dibagikan kepada ahli waris yang ada, tetapi untuk anak dalam kandungan harus disisihkan bagiannya. Besar kecilnya ditentukan mana yang lebih menguntungkan antara diperkirakan lakilaki ataupun perempuan, kepastiannya baru diketahui setelah anak lahir.

Apabila ahli waris terdiri dari ayah, ibu, suami, 1 orang anak perempuan, dan 1 orang cucu dalam kandungan, untuk perhitungan waris anak dalam kandungan adalah:

\section{Tabel 3}

\begin{tabular}{lll}
\hline Ahli Waris & Fard & $\mathrm{AM}=2$ \\
\hline Istri & $1 / 8$ & $3 / 24$ \\
\hline
\end{tabular}




\begin{tabular}{llll}
\hline Ayah & \multicolumn{2}{c}{$4 / 6$} & $4 / 24$ \\
\hline Ibu & $1 / 6$ & $4 / 24$ \\
\hline 1 anak lk & A & $13 / 24$ \\
\hline \multicolumn{4}{c}{ Tabel 4} \\
\hline Ahli Waris & Fard & AM=2 & Rad $=23$ \\
\hline Istri & $1 / 8$ & $3 / 24$ & $3 / 23$ \\
\hline Ayah & $1 / 6+\mathrm{A}$ & $4 / 24$ & $4 / 23$ \\
\hline Ibu & $1 / 6$ & $4 / 24$ & $4 / 23$ \\
\hline 1 anak pr & $1 / 2$ & $12 / 24$ & $12 / 23$ \\
\hline
\end{tabular}

Dari perhitungan tersebut diatas, anak dalam kandungan disisihkan bagiannya yang paling menguntungkan yaitu sebagai anak laki-laki, kepastiannya baru diketahui setelah anak lahir.

\section{Ahli Waris Mafqud}

Orang hilang (mafqud) adalah orang yang meninggalkan tempat untuk beberapa lamanya tanpa diketahui keberadaannya. Apakah orang tersebut benar-benar mati atau tidak. Dalam hal ini yang menjadi persoalan adalah jika orang yang mafqud menjadi ahli waris ataupun menjadi pewaris.

Kedudukan orang yang mafqud dipandang hidup dalam hal-hal yang menyangkut hak-haknya dan dipandang mati dalam hal yang menyangkut hak orang lain hingga dapat diketahui mati atau hidupnya, atau terdapat keputusan hakim tentang mati atau hidupnya.

Akibat dari ketentuan tersebut adalah, harta bendanya tidak boleh diwarisi pada saat hilangnya sebab mungkin dalam suatu waktu dapat diketahui masih hidup, tidak berhak waris terhadap harta peninggalan kerabatnya yang meninggal setelah mafqud meninggalkan tempat. Namun, karena kematian mafqud tidak dapat diketahui dengan pasti, ia masih harus diperhatikan dalam pembagian warisan, seperti halnya anak dalam kandungan. Bagian mafqud harus disisihkan hingga dapat diketahui keadaannya, masih hidup atau telah meninggal, atau dengan keputusan hakim dinyatakan telah meninggal. Untuk mengetahui berapa bagian ahli waris yang ada, diperhitungkan dengan perkiraan bahwa mafqud masih hidup.

Tabel 5

\begin{tabular}{lll}
\hline Ahli Waris & Fard & $\mathrm{AM}=24$ \\
\hline Istri & $1 / 8$ & $3 / 24$ \\
\hline Ayah & $1 / 6$ & $4 / 24$ \\
\hline Ibu & $1 / 6$ & $4 / 24$ \\
\hline 1 anak lk mafqud (hidup) & $\mathrm{A}$ & $13 / 24$ \\
\hline \multicolumn{3}{c}{ Tabel 6} \\
\hline Ahli Waris & Fard & $\mathrm{AM}=12$ \\
\hline Istri & $1 / 4$ & $3 / 12$ \\
\hline Ayah & $\mathrm{A}$ & $6 / 12$ \\
\hline Ibu & $1 / 3$ & $3 / 12$ \\
\hline 1 anak lk mafqud (mati) & - & - \\
\hline
\end{tabular}

Dari dua perhitungan tersebut, bagian ahli waris yang ada lebih sedikit jika diperkirakan anak laki-laki mafqud masih hidup. Tetapi jika mafqud yaitu setelah keputusan hakim, mafqud dinyatakan telah meninggal, ahli waris yang berhak atas harta warisannya hanyalah yang ada pada waktu putusan hakim dijatuhkan.

\section{Konsep Hukum Penyelesaian Sengketa Ahli Waris khuntsa dalam Hukum Faraidh}

Berbicara mengenai sebuah konsep hukum akan lebih baik kita mengemukakan sebuah contoh konsep yang salah satunya dipakai oleh dan sering diterapkan dalam masyarakat, dalam penelitian ini penulis mengambil sebuah contoh praktek pembagian waris pada masyarakat Banjar, kenapa mengambil contoh praktek pembagian waris pada masyarakat Banjar karena 90\% masyarakat Banjar beragama Islam dan notabenenya menerapkan dan menegakkan 
syariat Islam dalam kehidupan mereka seharihari.

Salah satu konsep pembagian waris dengan cara Ishlah ialah dengan melakukan musyawarah mufakat, yang berarti prosesnya hanya menempuh satu jalan atau satu cara, yaitu musyawarah mufakat. ${ }^{9}$ Dalam masalah ini ahli waris bermusyawarah menentukan besarnya bagian masing-masing ahli waris dan penerima warisan lainnya. Pertimbangan atau dasar untuk menentukan besarnya bagian masing-masing ditentukan oleh kondisi objektif keadaan ahli waris dan penerima warisan lainnya, oleh karena itu bagian yang diterima oleh masing-masing ahli waris dan penerima warisan lainnya sangat bervariatif yang tidak memakai prosentase tertentu.

Dalam proses pembagian waris pada pola Faraidh-Ishlah, terlihat adanya kekhawatiran dari ahli waris tersebut tidak melaksanakan syariat agama Islam, sebab dalam hal ini rasa keberagamaan mereka menjadi taruhan utama dalam kehidupan. Sebab dalam hal Faraidh_Ishlah ini mereka merasa sudah melaksanakan syariat agama atau sesuai dengan apa yang diperintahkan oleh agama, walaupun kemudian mereka memilih untuk melakukan Ishlah agar pembagian tersebut dapat menyentuh aspek

\footnotetext{
9 Di daerah Kecamatan Astambul Martapura dijumpai beberapa model penyelesaian sengketa waris di antara keluarga yaitu dengan cara pertama membagi warisan dengan cara sama rata di antara ahli waris, membagi waris dengan jalan memperhitungkan peruntukan atau mereka sepakat untuk tidak membagi harta warisan berupa kebun dan sawah, namun hasilnya dibagi dengan sama rata, atau di antara mereka secara bergiliran menikmati hasil sawah atau kebun secara bergiliran. Lihat beberapa hasil penelitian Mahasiswa Fakultas Syariah IAIN Antasari Banjarmasin Tahun 1990. Ada juga peruntukan harta untuk tunggu haul. Model-model seperti itu biasanya setelah mereka mengetahui bagian masing-masing.
}

kemashlahatan keluarga.

Berbeda dalam hal pembagian warisan yang hanya dengan menggunakan cara Ishlah, mereka menganggap lembaga Ishlah ini juga dibenarkan oleh syariat Islam, karena masalah warisan adalah masalah muamalah yang pelaksanaannya diserahkan kepada umat, asalkan dalam hal tersebut tidak ada perselisihan. Dalam Kompilasi Hukum Islam (KHI) sendiri pasal 183 disebutkan bahwa para pihak ahli waris dapat bersepakat melakukan perdamaian dalam pembagian harta warisan, setelah mereka menyadari bagiannya. ${ }^{10}$

Berdasarkan Kompilasi Hukum Islam ini pada pola Faraidh - Ishlah yang selama ini diterapkan oleh masyarakat Banjar dalam pembagian warisan sudah sejalan (dalam penelitian ini diambil sebagai contoh adalah masyarakat Banjar yang mempraktekkan penyelesaian seperti ini), karena masingmasing pihak sudah menyadari besarnya bagian masing-masing sebagaimana yang sudah ditetapkan oleh tuan guru. Akan tetapi dalam hal pembagian harta warisan hanya dengan cara Ishlah patut dipermasalahkan, karena tanpa didahului oleh proses pembagian menurut Faraidh, sehingga ketentuan pasal 183 kompilasi hukum Islam itu tidak terpenuhi. Dalam hal ini berarti masyarakat Banjar melihat permasalahan tersebut bukan dari aspek Kompilasi Hukum Islam, melainkan melakukan pembagian warisan berdasarkan apa yang mereka anggap baik berdasarkan kemaslahatan mereka. Di samping itu pihak yang terlibat dalam proses pembagian warisan

\footnotetext{
${ }^{10}$ Asywadie Syukur ketentuan tersebut mengadopsi ketentuan hukum yang hidup pada masyarakat Banjar, beliau termasuk salah seorang tim pengkaji rancangan KHI, salah satu pasalnya adalah ketentuan Pasal 183 yang beliau perjuangkan. Lihat Abdurrahman, Kompilasi Hukum Islam di Indonesia, (Jakarta: Akademika Pressindo, 1992), 158.
} 
yaitu tuan guru yang tahu masalah agama tidak menghalangi cara Ishlah ini, dengan dasar bahwa masalah pembagian warisan (dalam keadaan tidak sengketa/perselisihan) adalah masalah muamalah yang tidak mutlak harus mengikuti Faraidh. Dengan kata lain pelaksanaan pembagian warisan berdasarkan Ishlah ini juga dibenarkan oleh syariat Islam.

Dari gambaran pembagian waris tersebut dapatlah dilihat bagaimana hubungan hukum adat dengan hukum Islam dalam masyarakat Banjar. Dalam hal ini berarti apakah hukum adat yang berlaku ataukah hukum agama yang berlaku. Sebagaimana diketahui teori yang menjelaskan hubungan antara keduanya terdapat tiga teori yang saling bertentangan, yaitu teori reception in complexu dan receptie theorie serta reception a contrario. Sebagaimana diketahui bahwa teori receprio ni complexu menyatakan bagi orang Islam telah melakukan resepsi hukum Islam dalam keseluruhan sebagaisatukesatuan, danreceptie theorie menyatakan bagi orang Islam yang berlaku bukanlah hukum Islam melainkan hukum adat. Walaupun ada pengaruh hukum Islam, tetapi ia baru dianggap sebagai hukum kalau diterima oleh hukum adat. Serta teori reception a contrario menyatakan bagi orang Islam berlaku hukum Islam, hukum adat baru berlaku kalau diterima oleh hukum Islam (tidak bertentangan dengan hukum Islam).

Melihat ketiga teori tersebut, bilamana dikaitkan dengan pembagian waris dalam masyarakat Banjar dapat dilihat hal-hal sebagai berikut:

1. Masyarakat Banjar melakukan pembagian waris dengan menggunakan syariat Islam (Faraidh);

2. Disamping menggunakan Faraidh masyarakat Banjar juga menggunakan lembaga Ishlah;
3. Lembaga Ishlah itu sendiri merupakan lembaga hukum yang hidup dalam masyarakat Banjar dan

4. Lembaga Ishlah ini ternyata diakui keberadaannya oleh tuan guru atau tokoh agama Islam, sehingga dapat ditafsirkan lembaga ini tidak bertentangan dengan syariat Islam.

Berdasarkan paparan di atas, maka dapat dikatakan bahwa pembagian harta warisan menurut hukum adat masyarakat Banjar dapat berlaku teori reception a contrario. Namun terlepas dari ketiga teori tersebut di atas ada satu teori yang dikemukakan oleh Otje Salman yang melepaskan diri dari ketiga teori di atas, yakni dengan mengajukan teori kesadaran hukum masyarakat yang intinya adalah bahwa hukum adat dengan hukum Islam memiliki taraf yang sejajar dalam daya berlakunya di Indonesia, di mana daya berlaku suatu sistem hukum tidak disebabkan oleh merepsinya sistem hukum yang satu dengan hukum Islam, tetapi hendaknya disebabkan oleh adanya kesadaran hukum masyarakat yang nyata menghendaki bahwa sistem itulah yang berlaku. ${ }^{11}$

Kalau dilihat dari teori kesadaran hukum masyarakat, maka pembagian warisan menurut hukum waris adat masyarakat Banjar dengan menggunakan Faraidh dan Ishlah merupakan hukum yang hidup dalam masyarakat. Karena kesadaran hukum masyarakat itu sendiri. Oleh karena itu telaahan teori kesadaran hukum masyarakat ini mencoba keluar dari perdebatan tarik menarik antara hukum Islam dengan hukum Adat. Akan tetapi sebenarnya teori ini kalau dilihat dari substansi asal hukum juga sulit

\footnotetext{
${ }^{11}$ Otje Salman, Kesadaran Hukum Masyarakat Terhadap Hukum Waris, (Bandung: Alumni, 1993), 25-28.
} 
menghindarkan dari perdebatan.

Bertolak dari uraian tersebut diatas dan contoh pelaksanaan pembagian waris oleh masyarakat Banjar, maka konsep penyelesain sengketa ahli waris khuntsa dalam Hukum Faraidh bisa dilakukan dengan memakai konsep Ishlah (mendamaikan) secara kekeluargaan yaitu berdasarkan kesepakatan para ahli waris, menurut penulis merupakan solusi yang bijaksana untuk menyikapi perbedaan kondisi ekonomi para ahli waris melalui sistemini ahli waris yang secara teoritis bisa mendapatkan bagian yang besar bisa saja menyerahkan bagiannya kepada ahli waris lain yang normalnya mendapatkan porsi yang lebih kecil tapi secara ekonomis membutuhkan perhatian khusus. Prinsip kesepakatan dalam pembagian waris yaitu prinsip kekeluargaan seeungguhnya didasarkan pada keyakinan para ulama bahwa masalah waris adalah hak individu dimana yang mempunyai hak boleh menggunakan atau tidak menggunakan haknya, atau menggunakan haknya dengan cara tertentu selama tidak merugikan pihak lain sesuai aturan standar yang berlaku dalam situasi biasa. Sistem Faraidh dalam Islam memberikan peluang kepada para ahli waris untuk membagi warisan atas dasar kesepakatan para ahli waris tersebut. Atas dasar kesadaran penuh dan keikhlasan setiap ahli waris, satu ahli waris bahkan bisa saja sepenuhnya menyerahkan haknya untuk diberikan kepada ahli waris lain atas dasar pertimbangan obyektif dan rasional. Ishlah yang dilakukan oleh ahli waris tidak boleh meninggalkan ilmu Faraidh, dengan kata lain, jika para ahli waris menginginkan Ishlah, maka tetap langkah awal dilakukan perhitungan Faraidh sehingga para ahli waris telah mengetahui pembagian masing-masing haknya, setelah ada kesepakatan para ahli waris barulah Ishlah dengan kerelaan masingmasing.

\section{PENUTUP}

Berdasarkan hasil penelitian serta analisis dan pembahasan yang telah dilakukan kesimpulan dalam penelitian ini adalah:

\section{Kesimpulan}

1. Konsep Pembagian Hukum Ahli Waris khuntsa dalam Hukum Faraidh, yang paling mendekati rasa keadilan adalah dengan mengambil bagian rata-rata dari dua perkiraan, sehingga baik diperkirakan laki-laki ataupun perempuan hasilnya ditambah dan dibagi dua.

2. Konsep Penyelesaian Sengketa Ahli Waris khuntsa dalam Hukum Faraidh bisa dilakukan dengan memakai konsep Ishlah (mendamaikan) secara kekeluargaan yaitu berdasarkan kesepakatan para ahli waris, merupakan solusi yang bijaksana untuk menyikapi perbedaan kondisi ekonomi para ahli waris melalui sistem ini ahli waris yang secara teoritis bisa mendapatkan bagian yang besar bisa saja menyerahkan bagiannya kepada ahli waris lain yang normalnya mendaptkan porsi yang lebih kecil tapi secara ekonomis membutuhkan perhatian khusus. Prinsip kesepakatan dalam pembagian waris yaitu prinsip kekeluargaan seeungguhnya didasarkan pada keyakinan para ulama bahwa masalah waris adalah hak individu dimana yang mempunyai hak boleh menggunakan atau tidak menggunakan haknya, atau menggunakan haknya dengan cara tertentu selama tidak merugikan pihak lain sesuai aturan standar yang berlaku dalam situasi biasa. Sistem Faraidh dalam Islam memberikan peluang kepada para ahli waris untuk membagi warisan atas dasar 
kesepakatan para ahli waris tersebut. Atas dasar kesadaran penuh dan keikhlasan setiap ahli waris, satu ahli waris bahkan bisa saja sepenuhnya menyerahkan haknya untuk diberikan kepada ahli waris lain atas dasar pertimbangan obyektif dan rasional. Ishlah yang dilakukan oleh ahli waris tidak boleh meninggalkan ilmu Faraidh, dengan kata lain, jika para ahli waris menginginkan Ishlah, maka tetap langkah awal dilakukan perhitungan Faraidh sehingga para ahli waris telah mengetahui pembagian masing-masing haknya, setelah ada kesepakatan para ahli waris barulah Ishlah dengan kerelaan masing-masing.

\section{Saran}

1. Karena ada beberapa pendapat dan konsep para ulama fiqih mengenai pembagian ahli waris khuntsa maka sebaiknya para ulama di Indonesia membuat suatu kesepakatan (Ijtihad) bersama yang disesuikan dengan hukum positif, dan hukum adat yang berlaku di Indonesia yang tidak bertentangan dengan syariat, agar menjadi acuan dalam hal penyelesaian sengketa bagi ahli waris khuntsa.

2. Konsep mengenai pembagian waris bagi ahli waris khuntsa yang sudah disepakati oleh para ulama di Indonesia dapat diajukan kepada pemerintah untuk dimasukkan dalam Kompilasi Hukum Islam, karena dalam Kompilasi Hukum Islam tidak memuat mengenai aturan pembagian ahli waris khuntsa, dan kedepannya Kompilasi Hukum Islam dapat ditingkatkan menjadi peraturan perundang-undangan.

\section{UCAPAN TERIMA KASIH}

Dengan memanjatkan puji syukur kepada Allah SWT Jurnal ini telah selesai dan rampung, terima kasih Penulis ucapkan kepada Ketua Yayasan Sekolah Tinggi Ilmu Hukum Sultan Adam Banjarmasin, Ketua LP2M Sekolah Tinggi Ilmu Hukum Sultan Adam Banjarmasin yang mendukung Penulis untuk menyelesaikan Jurnal ini sebagai wujud bentuk pelaksanaan Tri Darma Perguruan Tinggi.

Penulis menyadari dalam penulisan Jurnal ini masih jauh dari kategori sempurna, oleh karenanya Penulis berharap saran, kritik, masukan untuk perbaikan dalam penulisan Jurnal ini.

Dalam kesempatan ini juga penulis ucapkan terima kasih kepada Yayasan Pendidikan Tinggi Ilmu Hukum Indonesia STIH Sultan Adam yang memfasilitasi penulis dan memberikan pendanaan untuk biaya penulisan jurnal ini. Melalui jurnal ini Penulis berharap sebagai salah satu masukan/sumbangan pemikiran untuk ulama di Indonesia dalam hal membuat suatu kesepakatan (Ijtihad) bersama yang disesuikan dengan hukum positif, dan hukum adat yang berlaku di Indonesia yang tidak bertentangan dengan syariat, agar menjadi acuan dalam hal penyelesaian sengketa waris Miratsut Taqdiri. Konsep mengenai pembagian waris Miratsut Taqdiri yang sudah disepakati oleh para ulama di Indonesia dapat diajukan kepada pemerintah untuk dimasukkan dalam Kompilasi Hukum Islam, karena dalam Kompilasi Hukum Islam tidak memuat mengenai aturan pembagian ahli waris Miratsut Taqdiri, dan kedepannya Kompilasi Hukum Islam dapat ditingkatkan menjadi peraturan perundang-undangan

\section{BIBLIOGRAFI}

\section{Buku}

Abdurrahman. Kompilasi Hukum Islam di 
Indonesia. Jakarta: Akademika Pressindo, 1992

Basyir, Ahmad Azhar. Hukum Waris Islam. Yogyakarta: Penerbit UII Press, 2001.

Fathurrahman. Ilmu Waris, Bandung: AlMaarif, 1975.

Syarifuddin, Amir. Hukum Kewarisan Islam. Jakarta: Kencana, 2004.

Salman, Otje. Kesadaran Hukum Masyarakat Terhadap Hukum Waris. Bandung: Alumni, 1993

Thalib, Sayuti. Hukum Kewarisan Islam di Indonesia. Jakarta: Penerbit Sinar Grafika, 1995

\section{Jurnal}

Rizkal. "Pemberian Hak Waris dalam Hukum Islam Kepada Non-Muslim Berdasarkan Wasiat Wajibah," Jurnal Yudisial 9, no.2 (2016): 174. https://jurnal.komisiyudisial. go.id/index.php/jy/article/view/23

Utama, Sofyan Mei. "Kedudukan Ahli Waris Pengganti dan Prinsip Keadilan dalam Hukum Waris Islam." Jurnal Wawasan Yuridika 34, no.1 (2016): 73. http:// ejournal.sthb.ac.id/index.php/jwy/article/ view/109 